\title{
Crises and paradigms in macroeconomics
}

\author{
Malcolm Sawyer*
}

\begin{abstract}
Contrasts are drawn between mainstream macroeconomics (with the ,New Consensus in Macroeconomics taken as the current manifestation) and heterodox macroeconomics and their abilities to comprehend the financial crises and world wide recession of 2007 - on for macroeconomic paradigms is discussed. Specifically, the contrasting ways in which the two schools of thought treat unemployment, human behaviour, aggregate demand and money and credit are discussed. It is concluded that the events of 2007 - og once again cast doubt on the abilities of mainstream macroeconomics to confront the realities of capitalist economies.
\end{abstract}

$J E L$ classifications: $B 50, E_{I 2}, E_{I 3}$

Keywords: macroeconomic paradigms, new consensus in macroeconomics, heterodox macroeconomics, economic crisis

\section{Introduction}

The widespread economic depression of the I920s and I930s and the resulting high levels of unemployment exposed the general belief amongst economists in the self-correcting mechanisms of market capitalism. The birth of macroeconomic analysis, associated with works of authors such as Keynes and Kalecki, were ways of providing analysis and understanding of the prolonged occurrence of unemployment of labour and excess capacity. Many have recognized the revolutionary nature of their works, and analyses which were recognisably linked with their work became the orthodoxy of the I950s and I96os even though their analyses were presented and taught in ways which played down, and later eliminated, the

* University of Leeds, UK. I am grateful to Philip Arestis and two anonymous referees for helpful comments on earlier versions of the paper.

Correspondence Address:

Malcom Sawyer, Economics Division, Leeds University Business School, University of Leeds, Leeds LS2 9JT, UK, e-mail: m.c.sawyer@lubs.leeds.ac.uk.

Received 2I February 2010, accepted 23 June 2010

(C) INTERVENTION 7 (2), 20IO, 283-302 
core messages of their works. Then ıclassical economics` (to use Keynes's phrase) in various guises returned to dominance, whether under the heading of monetarism, New Classical Macroeconomics, New Keynesian economics and the `New Consensus in Macroeconomics` (hereafter NCM). These revivals of `classical economics`, which share the common characteristic of in effect re-instating Say's Law (to the effect that the level of aggregate demand will, sooner rather than later, adjust to the level of supply), have pushed the essential features of the analyses of Kalecki, Keynes and others into the margins of the economics profession. The 'great recession ‘ of 2007 - 09, as the 'great depression I930s did, raises fundamental questions about the nature of macroeconomic analysis, and the usefulness of forms of macroeconomic analysis which largely deny the cyclical nature of capitalist economies and the prevalence of unemployment of labour. It is though fortunate that one of the essential lessons of the analyses of Kalecki and Keynes, namely the folly of seeking to restrain budget deficits in the face of economic downturn and the need to use fiscal and monetary policy to stimulate rather than further deflate the economy, was remembered and its application prevented the 'great recession becoming the 'great depression ${ }^{\mathrm{I}}{ }^{ }$

In this paper we seek to explore some of the implications of the occurrence of the rgreat recession ` of 2007 - o9 for paradigms of macroeconomic analysis, and do so through some comparisons between two paradigms which we will label mainstream and heterodox. We will assert that there are sufficient common features between approaches which have been labelled monetarist, New Classical, New Keynesian, real business cycle etc. to treat them together, and specifically we use the 'New Consensus in Macroeconomics` as the most recent manifestation of this, and refer to books such as Woodford (2003) as expressions of the mainstream approach. One contrast between mainstream macroeconomics and heterodox macroeconomics is that the latter is genuinely macroeconomics whereas the former is often little more than radded up microeconomics. Hence heterodox macroeconomics is genuine macroeconomics in the sense that it is not

"a first simplified rough step towards a more detailed and disaggregated analysis. It is macro-economic because it could not be otherwise. Only problems have been discussed which are of a macro-economic nature; an accurate investigation of them has nothing to do with disaggregation. They would remain the same - i.e. they would still arise at a macro-economic level - even if we were to break down the model into a disaggregated analysis« (Pasinetti 1974).

The heading of heterodox macroeconomics is intended to be an encompassing one drawing on macroeconomic analysis which may be viewed as Keynesian, post-Keynesian, Kaleckian (and post-Kaleckian), Marxian etc. We share with Lavoie the view that "heterodox economists do have a lot in common, and the belief that heterodox economics goes well beyond the critique of mainstream economics" (Lavoie 2006a: 90). At the general level of economic analysis, Lavoie asserted that the

I At the time of writing (June 20IO) there are clear danger signs that the lessons are being overlooked as many countries introduce 'fiscal consolidation. 
"distinctiveness of heterodox economics vis-à-vis neoclassical economics rests on four pairs of presuppositions. These are: realism versus instrumentalism, organicism versus methodological individualism, production versus exchange, and procedural rationality versus substantive rationality.« (Lavoie 2006a: 9I)

He also argued that

"heterodox authors share a pricing theory that has a number of similarities. They all draw on a very flexible tool - the Kaleckian model of growth. Founded on the principle of effective demand, this model can be used to study a very large number of macroeconomic questions by introducing a variety of theories and hypotheses. Finally, I believe that at this moment, there is an extraordinary convergence amongst heterodox macroeconomists who are trying, through diverse means, to incorporate financial and monetary questions in the framework of models dealing with real variables." (Lavoie 2006a: 105).

In that spirit and at relatively concrete level and with specific reference to heterodox macroeconomics, in Sawyer (2009a) I identified eight general features which are. ${ }^{2}$

I. the level of demand is always important for the level of economic activity in the longrun (however that is defined) as well as the short-run;

2. the key roles for investment as a relatively volatile component of aggregate demand, the driving force in the savings-investment relationship, and as involving the creation of productive potential;

3. the impact of the distribution of income on the level of demand;

4. the interdependence of aggregate demand and aggregate supply, the denial of the classical dichotomy and the manner in which the path of demand influences the development of the economy's supply potential;

5. the analysis of a monetary production economy in which money is endogenously created (and destroyed) through the operation of the banking system and where credit sbooms and busts` are endemic;

6. the determination of prices based on firms operating in oligopolistic markets with the price-costs margins dependent on the market power of firms and the determination of wages subject to a range of factors including efficiency wage type arguments through to collective bargaining (and largely eschewing wages set in labour markets which approximate perfect competition);

7. inflation is not seen as a monetary phenomenon (in the sense of caused by monetary growth), but rather arises in a range of ways (which differ over time and over country) including from a struggle over income shares, the level of and rate of changes of the level of aggregate demand and cost-push factors coming notably from the foreign sector (change in import prices and the exchange rate);

2 See also Goldstein/Hillard (2009a), Goldstein (2009). 
8. economies are open and as such are subject to the vagaries of the financial markets through their exchange rate and capital inflows and outflows, having significant effects on the domestic economy.

There is an interplay between the perceived state of the macroeconomy and macroeconomic theory. Periods of sustained growth and low unemployment tend to lead to claims of an rend of the business cycles, and theory based on the absence of slumps and near full employment gain credence. ${ }^{3}$ Periods of slump and rising unemployment can foster interest in theories which are consonant with such occurrences. In the recent period, the claims of the end of the business cycle couched in terms of the arrival of the "great moderation " (Bernanke 2004, now Chair of the Federal Reserve, and general use), the »NICE« (non-inflationary continuous expansion) (King 2003, now Governor of the Bank of England) and the end of "boom and bust" (claims in the UK by the Labour government) ${ }^{4}$. This igreat moderation was often ascribed to the success of the policy regime of inflation targeting and nondiscretionary fiscal policy. The world-wide recession (and also the rise in inflation in 2008 to around 5 per cent in many industrialised countries) casts grave doubts on these claims to say the least. It is not just that the adoption of a particular policy regime was often claimed to be responsible for sthe great moderation`, but that the theory itself (e.g. the 'New Consensus in Macroeconomics ) was strongly based on the absence of significant fluctuations in economic activity and provides little understanding of the causes of fluctuations and unemployment. ${ }^{5}$ In effect, within the NCM, the explanation of ` booms and busts ‘ comes from decision making errors by the Central Bank in the setting of the (policy) interest rate with booms coming from the interest rate being set well below the 'natural rater of interest, and busts from the interest rate being too high.

Specifically with regard to the financial markets, a number of commentators have pointed to how the dominance of the refficient markets a approach to finance lead to a Panglossian view of the financial markets in which, for example, movements in prices reflect all available information on future prospects (for example, Krugman 2009). The refficient market approach to finance is one based on optimising individuals operating in an environment of competitive markets where individuals have 'good information about a knowable future. In effect, the RARE (rational agents, rational expectations) model operates. This has been important with respect to the analysis of financial markets but the same basic approach to human behaviour and markets has been evident in mainstream macroeconomic theory such

3 Although rather strangely the crisis of the mid I970s and then the early I980s spawned the New Classical Macroeconomics with its denial of involuntary unemployment.

4 For example, in 2007, "And we will never return to the old boom and bust (Brown 2007); »In previous decades instability and spiralling inflation too often pushed Britain's economy from boom to bust. In the past decade we have put that instability behind us, and have reaped the rewards" (Darling 2007).

5 For an early statement of the NCM see Meyer (200I), for a formal and extensive elaboration see Woodford (2003), for some essays on NCM see Arestis (2007a), and for a critique of the NCM see Arestis/Sawyer (2008). 
as the NCM. It is widely acknowledged that the financial crisis has severely undermined the refficient markets` approach and the rrational expectations NCM (and most of mainstream macroeconomics) is firmly based on `rational expectationsı, and the policy conclusions which are derived from the NCM are reliant on ideas of markets clearing and `rational expectations`, specifically with regard to the irrelevance of fiscal policy and the virtual absence of economic fluctuations and of significant unemployment.

The paper considers three topic areas in which the mainstream approach and the heterodox are contrasted. Section 2 focuses on the occurrence of unemployment of labour and excess capacity which did not disappear under the 'great moderation ‘ but with the rapid rise in unemployment in 2008 onwards comes into prominence again. Section 3 addresses the modelling of human behaviour. Section 4 considers the nature and role of money and credit. Section 5 briefly concludes.

\section{Unemployment and excess capacity}

The occurrence of substantial levels of unemployment of labour and of excess capacity strike at the very heart of mainstream economic analysis and the defined purpose of economics. A widely used definition of economics came from Robbins when he wrote of economics as "the science which studies human behaviour as a relationship between ends and scarce means which have alternative uses " and thereby economic analysis "focuses attention on a particular aspect of behaviour, the form imposed by the influence of scarcity (Robbins I932). As Joan Robinson remarked, I932 was not the most appropriate time to make this definition since the major economic problem of the time was not the scarcity of resources but rather a scarcity of demand for those resources.

The argument here is more than dissonance between theory and observation. It is rather that the occurrence and persistence of unemployment runs completely counter to the widely used definition of the subject matter of neoclassical economics. Thus neoclassical economic analysis (which can be seen as encompassing the NCM) finds great difficulty in reconciling its definition of its own subject matter with the evidence of involuntary unemployment and excess capacity. The central role played by unbounded rationality in mainstream macroeconomic analysis is clearly evident, yet the waste of resources evidenced by unemployment and excess capacity appear as clear evidence of irrationality. The whole thrust of mainstream economics has been towards models in which equilibrium is characterised by full employment with the general presumption that there are strong forces at work which lead to equilibrium and hence to full employment. Observed deviations from full employment can be variously explained, whether through mis-perceptions, responses to technological shocks etc. but those explanations generally carry with them the notion that employment fluctuates around full employment, sometimes involving unemployment and sometimes overemployment. Other explanations have generally explored a variety of simperfections - the route initially pursued by New Keynesian economics. The 
agenda has then been based on full employment as the norm with explanations sought for deviations from full employment.

Heterodox macroeconomists view unemployment as a general characteristic of capitalist economies, with possibly occasional times when full employment is achieved. Kalecki, for example, argued that under capitalism

"a considerable proportion of capital equipment lies idle in the slump. Even on average, the degree of utilisation throughout the business cycle will be substantially below the maximum reached during the boom. Fluctuations in the utilisation of available labour parallel those in the utilisation of equipment. Not only is there mass unemployment in the slump, but average employment throughout the cycle is considerably below the peak reached in the boom. The reserve of capital equipment and the reserve army of unemployed are typical features of capitalist economy, at least throughout a considerable part of the cycle." (Kalecki I99I: 3II).

Unemployment as a concern of macroeconomics has largely disappeared from the mainstream macroeconomics. This is most evident in the concept of the snatural rate of unemployment identified as a market clearing position with demand and supply of labour equal, and hence the suppliers of labour satisfying their supply decisions, and the general presumption that the economy will operate at or around this snatural rate of unemployment $\triangleleft{ }^{6}$ At the 'natural rate of unemployment‘, any non-employment is then a matter of choice and involuntary unemployment is virtually ruled out.

"Unemployment in the unhampered market is always voluntary. In the eyes of the unemployed man, unemployment is the minor of two evils between which he has to choose" (von Mises 1949: 596),

"Workers who lose jobs, for whatever reason, typically pass through a period of unemployment instead of taking temporary work on the spot labour market jobs that are readily available in any economy [...] To explain why people allocate time to a particular activity - like unemployment - we need to know why they prefer it to all other available activities« (Lucas 1987: 54).

There may be some recorded unemployment but that would be seen as arising from some combination of choice and misperceptions on prices and wages. Unemployment is then nothing to worry about, and indeed any periods of underemployment are balanced by periods of overemployment.

The non-accelerating inflation rate of unemployment (NAIRU) is (in general) not itself a position of full employment, but it is a form of supply-side equilibrium. The level of unemployment may fluctuate around the NAIRU through fluctuations in aggregate demand

6 As de Vroey (1997) argues, Keynes could have readily agreed with Friedman on the definition of the snatural rate of unemployment as corresponding to full employment but differ in the major respect as to whether there was a strong feedback mechanism leading actual unemployment to the natural rate. 
or other reasons but the underlying rate of unemployment is the NAIRU. Unemployment is then ascribed to supply-side failures rather than demand failures, and indeed policies directed towards labour market de-regulation and liberalisation have been frequent proposals directed towards lowering the NAIRU.

There are other routes through which the involuntary unemployment of labour virtually disappears as a macroeconomic problem. First, estimates of the NAIRU based on econometric work are very likely to fall in the range of observed unemployment rates, and hence actual unemployment does not deviate systematically from the estimated NAIRU. When the NAIRU is seen as the rate of unemployment which corresponds to wages (adjusted for productivity) and prices rising at the same rate, and hence wage share constant, then in periods when the wage share does not change greatly, it must be the case that the estimated NAIRU falls well within the range of observed unemployment. Similarly if the NAIRU is seen as wages (or prices) rising in line with expected wage (or price) inflation, then in an era where wage (or price) inflation does not display a marked trend, the estimated NAIRU will be in range of observed unemployment. Thus comparisons between estimated NAIRU and actual unemployment will show a broad similarity and on average difference between estimated NAIRU and actual unemployment will be close to zero. At least it will appear that there is not demand deficient unemployment.

Second, attention has been shifted (in terms of the representation of the supply side in macroeconomic models) from unemployment to the output gap: this is exemplified in the presentation of the NCM (see, for example, Arestis 2007b). The output gap, being the difference between actual output and trend output, will tend to average out at zero by construction as the estimates of trend output are derived from actual output. ${ }^{7}$ The trend level of output is viewed as a supply-side equilibrium and generally as having some desirable properties as the optimal level of output (as reflected in the use of a quadratic loss function involving output gap so that output above trend generates the same loss as output below trend to the same extent). It also serves to distract attention away from unemployment.

Although unemployment has been always present in the real capitalist world, and on any reasonable definition full employment of labour is a rather rare occurrence under market capitalism, the world-wide 'great recession` brings the issues of unemployment once again to the fore. The mainstream approach centred on the non-occurrence of unemployment in any meaningful sense is unable to provide any explanation. Indeed the manner in which the NCM is set up to include a form of Say's Law and Ricardian equivalence precludes significant departures from full employment. ${ }^{8}$ In contrast, the heterodox approach

7 There may be some differences in so far as trend output is estimated on the basis of past trends and extrapolated over a period when (at least in retrospect) the trend growth rate is different.

8 Say's Law, supply creates its own demand, is widely incorporated in mainstream macroeconomics through the emphasis on optimisation subject to a budget constraint. The budget constraint (e.g. for the household) is of the form of expenditure on goods and services less than or equal to income from factor supply, and the non-satiation assumption pushes this to expenditure equals income, demand equals supply. Ricardian equivalence is based on the idea that the liabilities of government rep- 
has a ready explanation arising from the failures of the financial system and the collapse of aggregate demand.

In the heterodox traditions at least three strands of explanations for unemployment of labour can be readily identified. First, at one level, the failures of private aggregate demand, arising from tendencies for the overall propensity to save to exceed the overall propensity to invest, are the cause of low levels of economic activity. It is rather self-evident that the unemployment rate fluctuates over the course of the business cycle in response to fluctuations in aggregate demand, and that at best something like full employment is only achieved at the top of the cycle. But it could be said, in line with Kalecki (1943), that now that it has been established that sufficient government expenditure can address the failures of private aggregate demand, that, notwithstanding the practical problems of a fiscal policy to ensure high levels of overall demand, the attention should be shifted to the political and social forces which prevent the use of effective fiscal policy.

Second, a more structuralist perspective is that there is insufficient productive capacity to be able to accommodate the full employment of labour. This insufficiency may be exhibited in what appear to be high levels of the NAIRU where higher levels of demand would generate inflationary pressures through a lack of productive capacity (see Arestis/Sawyer 2005). The insufficiency could show up in terms of supply bottlenecks where the expansion of the economy is held back by an inability to supply key outputs. The insufficiency would also appear in the form of structural unemployment, specifically in the forms of high levels of localised unemployment.

Third, the roles of the threats and actuality of unemployment in the functioning of a capitalist economy. This can find several forms of expression. In a more mainstream approach, the NAIRU is not only the rate of unemployment which is thought to correspond to a constant rate of inflation, it is also the rate of unemployment which rresolves the conflict between capital and labour over the distribution of income. On the edges of the mainstream, approaches such as those of Shapiro and Stiglitz (1984), Bowles and Boyer (I988), emphasise the role of unemployment in the disciplining of workers (limiting shirking in Shapiro/Stiglitz 1984). Kalecki's expression was that under sustained full employment

»the social position of the boss would be undermined, and the self-assurance and class consciousness of the working class would grow. Strikes for wage increases and improvements in conditions of work would create political tensions« (Kalecki I991: 35I).

He suggested that "discipline in the factories« and "political stability« would also be undermined.

resented by the public debt are taken into account in private decision making to the extent that a one unit increase in public expenditure and in budget deficit is offset by a one unit decrease in private expenditure. Ricardian equivalence would then rule out the effectiveness of fiscal policy. But at the same time, it cannot account for a slump in private demand (as during the sgreat recessions) leading to economic downturn and larger budget deficits. 
Thus, we would argue, the heterodox approach has generated a range of causes of involuntary unemployment, views which are not in conflict and the weight of which vary over time and space. In contrast, the mainstream approach often ignores unemployment, reducing it to a voluntary choice, and has at most provided an imperfectionist explanation of unemployment based on departures from perfect competition.

\section{Micro-economic foundations and human behaviour}

The mainstream approach has made much of having well-founded microeconomic foundations. It has been a frequent attack on heterodox macroeconomics (particularly Keynesian macroeconomics) that it lacks rigorous microeconomic foundations. In contrast, it is then argued that mainstream macroeconomics has well-founded microeconomic foundations. The lines of argument pursued here are that the microeconomic foundations claimed by the mainstream macroeconomists are a major weakness and that a macroeconomic analysis based on those micro foundations has not been established. Further, heterodox macroeconomics has always had microeconomic foundations, but the nature of those foundations have differed between authors (as is illustrated above in the case of investment decisions). But Solow argues

"that the claim that smodern macro somehow has the special virtue of following the principles of economic theory is tendentious and misleading." (Solow 2008: 244).

He then describes the models of the mainstream macroeconomics as deduced

"from a model in which a single immortal consumer-worker-owner maximizes a perfectly conventional time-additive utility function over an infinite horizon, under perfect foresight or rational expectations, and in an institutional and technological environment that favors universal price-taking behavior. In effect, the industrial side of the economy carries out the representative consumer-worker-owner's wishes.« (243).

Even when imperfections are added

"basically this is the Ramsey model transformed from a normative account of socially optimal growth into a positive story that is supposed to describe day-to-day behavior in a modern industrial capitalist economy. It is taken as an advantage that the same model applies in the short run, the long run, and every run with no awkward shifting of gears. And the whole thing is given the honorific label of dynamic stochastic general equilibrium."«

Instead, he argues that

"a modern economy is populated by consumers, workers, pensioners, owners, managers, investors, entrepreneurs, bankers, and others, with different and sometimes conflicting desires, information, expectations, capacities, beliefs, and rules of behaviour" (Solow 2008: 243). 
"Economic man« is a "man for all seasons « in the sense that it appears applicable to all situations and choices - all that is required for a particular analysis is to identify the variables which enter the utility function which is optimised - of course in principle everything would enter the utility function which is optimised with respect to the budget constraint. The only question then is for a specific investigation what simplifications can be made for example in the analysis of labour supply the utility function is taken to include leisure time and income.

Mainstream macroeconomics (with its base in neoclassical microeconomic theory) emphasises choice, and that outcomes are reflections of choices and preferences. The choices of sets of individuals have somehow to be reconciled, e.g. equilibrium between demand and supply, but often in macroeconomic theory it is assumed that one side of the market dominates, e.g. supply. In contrast, the heterodox approach stresses the pressures on reconomic agents - not denying there is an exercise of choice but that the room for manoeuvre by the individual is limited and how the choices and decisions of individuals are socially conditioned. Perhaps the clearest example of this relates to the supply of labour $:$ the orthodox approach is clearly based on maximising utility based on leisure (and labour as nonleisure) and income (and in turn the utility of income comes from consumption) subject to budget constraint. In contrast, a heterodox approach would stress the social conditions which sets the scene for who works and who does not (e.g. age of retirement), the pressures on those of the working age population to work arising from the need to survive (Sawyer/ Spencer, 20IO). Another example would come from investment decisions. The mainstream approach would focus on profit maximisation whereas a heterodox approach would recognize the role of profits but also the competitive pressures on firms.

The mainstream approach purports to portray human behaviour as >rationalı. In doing so a rather limited notion of rationality in mainstream economics is used, that of consistency over choices. It is not doubted here that an individual would act rationally in the sense that if $\mathrm{X}$ is preferred to $\mathrm{Y}$, and $\mathrm{Y}$ to $\mathrm{Z}$ then $\mathrm{X}$ is preferred to $\mathrm{Z}$ in situations where the individual is able to consider the three options and has clear perceptions on the benefits or otherwise of $\mathrm{X}, \mathrm{Y}$ and $\mathrm{Z}$. This would not though preclude that $\mathrm{X}$ is preferred to $\mathrm{Y}, \mathrm{Y}$ to $\mathrm{Z}$ today but $\mathrm{Z}$ is preferred to $\mathrm{X}$ tomorrow through changes in perception of what $\mathrm{X}, \mathrm{Y}$ and $\mathrm{Z}$ involve and/or through changes in tastes and preferences (or desire for variety). Any notion of sunbounded rationality incomplete knowledge and information, through lack of scomputer power and the essential unknowability of the future.

The rationality of the RARE approach involves much more than the consistency view of rationality at the individual level. It involves a rationality coming from knowledge of the future, and it involves a rationality in the sense that all beneficial trades have been undertaken. Disequilibrium in any market is a sign of irrationality in the sense that not all beneficial trades have taken place. Unemployment is irrational in that not all resources are fully utilised in the context of scarcity, and also in the sense there are individuals wanting (and needing) to work and produce and individuals wanting to acquire the goods and services which would thereby be produced. 
This idea of rationality is related to the individual economic agent, and does not readily carry over to the organisation as economic agent. The simplest argument here is by way of appeal to Arrow's impossibility theorem (Arrow 1950), that is that even where individuals decide rationally (as defined above), it does not follow that decisions made through some voting mechanism will display corresponding rationality. The mainstream approach within macroeconomics has retained a single well-defined objective for the firm, and in effect the firm is also an individual. When a firm is considered as a social organisation, then individual rationality cannot be presumed to translate into organisational rationality.

The micro foundations of mainstream macroeconomics which have been cited as a major strength are rather major weaknesses with the reliance on the RARE model. The two key weaknesses are having a microeconomic analysis which is aggregated on the basis of a representative agent approach does not provide a macroeconomic analysis (in the sense of Pasinetti) since the conditions for aggregation have not been established, and a reliance on the representative agent approach precluding differences between individuals and groups.

The NCM model, along with other mainstream models, is based on a representative agent approach (perhaps more accurately a representative household). Under such an approach, the problems of co-ordination in a decentralised market economy are inevitably played down. This co-ordination aspect of macroeconomics came to the fore with the reappraisal of Keynesian economics literature. In the heterodox traditions the focus has been on the co-ordination of savings and investment decisions as key though unemployment can also be seen through the lens of co-ordination issues - there are people willing to work, and there are people wanting to buy the products which would be produced. The representative agent approach overcomes issues of co-ordination - if I am a representative agent, then how I behave will be in effect followed by all others. The representative agent could also be linked to the assumption of similar behaviour in terms of utility maximisation. The representative agent has difficulty coping with issues such as differences in expectations.

A second weakness in the microeconomic analysis is the RARE approach which ignores the specific institutional arrangements of an economy and which plays down the constraints under which individuals and firms operate.

The RARE approach runs into two sets of objections. The first set is based on ideas of sbounded rationalityı, asymmetric information, perceptions and social conditioning of utility. The significance of the bounded rationality is in part that people behave in ways which are substantially different from maximisation - e.g. satisficing, that how decisions are framed and which options are considered become important. It is not a matter that `mistakes` are made so that actual decisions differ from those 'predicted by RARE but that there are systematic differences. This is well illustrated by rational expectations: it is not seen that expectations are always exactly accurate but rather that mistakes are stochastic. Indeed it was a key criticism of adaptive expectations that they could lead to persistent mistakes. But if adaptive expectations are interpreted as expectations on which decisions and actions are based and which arise from a person's experience and perceptions, it seems difficult to deny their role. The strick then becomes how experience is interpreted, how are perceptions formed etc. 
The second set is based on a view of the world as one of fundamental uncertainty where the future is yet to be revealed and where the economy is path dependent. The world is just not like the one portrayed by the rational expectations approach.

In an uncertain (in Keynes's sense) world where the future is yet to be discovered and where individuals lack the capacity to compute optimal decisions (and in any case the optimisation problem cannot be formulated in an uncertain world), then how individuals and organisations frame decisions and what operating rules of thumb are pursued become significant in understanding individual decisions. For macroeconomic analysis a detailed understanding of individual decisions is not required (and indeed given our own limited ability to incorporate information would provide us with far too much information than could be used). It is rather that ways of thinking about the major influences on key decisions is required. Take again the case of investment decisions. Rather than seeking to replace the neoclassical theory of investment under which firms optimise over an essentially known future, it would be to investigate the macroeconomic variables which influence investment, how the environment in which the firm operates (competition, owner/management controlled) is relevant for investment, and how perceptions of the future (the waves of optimism and pessimism) impact on investment decisions.

Those who would be regarded amongst the founders of heterodox macroeconomics, notably Keynes and Kalecki, clearly had microeconomic foundations for their macroeconomic analysis. In the cases of Kalecki and Keynes the microeconomic foundations which they provided were different and largely also focused on firm behaviour with respect to pricing and investment decisions (though household behaviour on consumption and labour supply were also included). Heterodox macroeconomics has not and would not wish to bring forward a universal set of microfoundations comparable to the manner in which the mainstream economists proceed. Heterodox macroeconomics has to grapple with the heterogeneity of behaviour and actions at the individual and organisational levels and with that behaviour in the context of fundamental uncertainty.

These arguments can be illustrated by reference to the treatment of investment decisions and expenditure in heterodox macroeconomics. Investment decisions are made and implemented by firms, and hence the amount of investment undertaken depends on the objectives of the firms, their organisation structure and goals as well as the market structure and competitive framework within which they operate, not to mention the nature of the financial system from which funds may have to be secured. Heterodox macroeconomists have provided many analyses of investment, based on different approaches to firms' organisation and behaviour. The pace of investment at any time has also to be understood in the context of the prevailing technological paradigm. There is broad agreement on the macroeconomic variables which influence investment, namely profitability as a source of finance and as a spur to capital accumulation, and the level and change in capacity utilisation through some form of accelerator mechanism.

There are four particularly significant aspects to the heterodox analysis of investment relevant here. First, there are clearly micro-economic analyses of investment which can be treated as within the heterodox. Whilst both Kalecki and Keynes analysed the roles of invest- 
ment expenditure as a component of aggregate demand, they also put forward firm-based analyses of investment. Later authors such as Eichner (1976) and Harcourt and Kenyon (I976) developed theories of investment which were widely regarded as post-Keynesian theories. Authors such as Crotty (I990), Fazzari and Variato (I994 and 1996) also provide analyses of investment behaviour, and Driver (1994) and Mott (2003) provide some reviews. Hence, any idea that heterodox macroeconomics is not concerned with micro decisions is clearly false.

Second, there are though different analyses of investment, which is a reflection of the different situations under which firms operate, different objectives, different institutional arrangements. The notion of having a universal (neoclassical) analysis of investment really makes little sense. Heterodox macroeconomics often has an sembarrassment of riches in terms of the analyses of investment behaviour (and also in other ways such as pricing behaviour). Whereas the mainstream approach relies on a neoclassical approach to investment, as introduced by Jorgenson (1963), heterodox macroeconomics has many approaches. The different approaches are, in part, a reflection of different views on how the 'world works and what are the driving forces behind accumulation. They are also a reflection that firms in different competitive situations and with different governance structures behave in different ways - there is no universal theory of investment behaviour.

Third, within the heterodox approaches there is recognition of fundamental uncertainty and the implications which that has for modelling investment behaviour which involves making decisions in the present which have future effects.

Fourth, investment behaviour is more than just a pale reflection of household savings behaviour, which has been the prevailing view in mainstream economics. Blanchard (2008) notes the absence of investment in the aggregate demand model in what he calls the stoy model of mainstream macroeconomics, and the ways in which the approach is based on optimisation, though we would add there is no consideration of the meaning of optimisation in a world of fundamental uncertainty.

The heterodox approach to investment is also illustrative of a major and highly significant difference between mainstream and heterodox macroeconomics.

"Suppose one were to ask the typical 'person on the street which agents or institutions are the movers and shakers in modern capitalist economies? I strongly suspect that business firms, perhaps in the form of the large corporation, would appear at the top of the list. Firms hire and fire. Firms set prices. Firms develop the technologies and invest in the capacity to transform labor into goods. Firms determine what consumers can buy. Yet, mainstream economic models present the firm as a remarkably passive agent. Especially in macroeconomic theory, the firm is usually portrayed as a technological automaton that mechanically spits out a homogeneous final product from simplistic labor and capital inputs to maximize its owners' profits (or net present value)«(Fazzari 2009: IOI).

The recognition of heterogeneity of actions, decisions and behaviour of firms and households is a major strength of the heterodox macroeconomics, and does not compress human behaviour to the dull uniformity of the representative agent. But this can present issues for 
the construction of macroeconomic models in that precise functional relationships cannot be readily derived, though this is a reflection of the messy real world. There are, for example, different approaches to pricing behaviour (see Lee 1998, Sawyer 1983), to investment behaviour (surveyed, for example, in Baddeley 2003) and wage determination (Sawyer 2002). Thus precise relationships at the aggregate level would be difficult to come by - and clearly it would not be possible to replicate at the aggregate level any microeconomic relationships. It may be possible to develop broad relationships for the aggregate level but ones lacking precision. For example, in Sawyer (1983) it was argued that the similarities between different pricing equations could be utilised to postulate that prices would be a (perhaps quadratic) function of the level of output, of input prices and the mark-up. In a similar vein Sawyer (2002) points to similarities between different views of wage determination, specifically in the sense that many imply a positive relationship between real wages and employment.

Macroeconometric estimation has to utilise aggregate or sub-aggregate relationships (e.g. for pricing, an equation at the aggregate or sectoral level), and these cannot be based on precise relationships. Even if it were possible in a heterodox approach to derive a precise relationship between variables at the level of the household or the firm, given what we have said about the different ways in which households and firms behave and the different pressures to which they are subject, any formal aggregation to yield a well defined functional relationship between aggregate variables is well nigh impossible.

In this section we have sought to sketch the argument that heterodox macroeconomics has, and always has had, micro-economic foundations, but ones which differ in so many ways from those of mainstream macroeconomics (see Fazzari 2003 for arguments along similar lines). The mainstream approach has been firmly based on the RARE approach, and specifically the manner in which it leads into notions of efficient markets and market clearing clash with the recent experiences.

\section{Money and finance}

Heterodox macroeconomics has always been firmly based around the concept of a monetary production economy in which it is not possible to separate the operations of the real side of the economy from the monetary and financial sides. A key aspect of the significance of effective demand is the notion that in a market economy demand (in the sense of desire for goods and services) can only be made effective in the market through the possession of purchasing power - that is money.

The difficulties which the mainstream analysis has in dealing with money and credit are well-known. This is reflected in

"the most serious challenge that the existence of money poses is this: the best developed model of the economy cannot find room for it. The best developed model is, of course, the Arrow-Debreu version of Walrasian general equilibrium« (Hahn 1983: I). 
The mainstream approach has generally seen 'money as a veil. At the level of the individual household, the "unified decision hypothesis« (using the words of Clower 1965) is generally used in which a household makes decisions with respect to goods and services and factor supplies simultaneously, and is in effect modelled as exchanging labour and other factor supplies for goods and services. At most, money is an intermediary in that process. Clower then pointed to the issues which arose when the first set of transactions (selling factors) could not be carried through, and to the sdual decision hypothesis', which lead into the reappraisal of Keynesian economics literature.

Within the context of macroeconomic analysis (recognising that there is also a flourishing monetary economics) the stock of money has often been envisaged as rexogenous, as exemplified in the Quantity Theory of Money and in monetarism. It was always paradoxical that monetarism was seen as 'money matters, which may have been relevant for the price level and the rate of inflation, but for the level of economic activity, the composition of output and the development of productive capacity the stock of money would be irrelevant. The rclassical dichotomy` ruled.

The development of the NCM has brought in some notion of endogenous money with the replacement of the given stock of money assumption of monetarism and other mainstream macroeconomics analysis with the assumption of a given interest rate set by the Central Bank. In turn, the manner in which the interest rate is set can be endogenised through some form of decision making rule such as Taylor's rule. This enables an alternative yet simple representation (see, e.g. Carlin/Soskice 2009 and other papers in Fontana/Setterfield 2009) of a macro model with the LM curve replaced by horizontal line in interest rate - income space. But the NCM does not reflect the importance and significance of endogenous money. ${ }^{9}$ Any instability within the context of the NCM comes from inappropriate decisions made by the Central Bank over the policy interest rate. It does not contain any hint of instability arising from the operations of the banks themselves nor does it consider the importance of decisions made by banks over loans to be provided and on what terms.

Heterodox macroeconomic analysis has a long standing recognition of the importance of the roles of money, credit and finance for the level of economic activity and for the instabilities of the capitalist economy. In the past few decades, the post-Keynesian approach has become closely identified with the ideas of endogenous money` (particularly stimulated by Moore 1988). The post-Keynesian analyses have their differences, notably between the accomodationists and structuralists (Lavoie 2006b, Dow 2006), but all recognise the essential endogeneity of money arising from the loan and credit creating processes of banks. In Sawyer (2009b) we argue that endogenous money has implications for macroeconomic analysis which cannot be simply summarised by replacing the LM curve by a horizontal line in interest rate - income space as is now envisaged by many mainstream economists (e.g. Romer 2000). In the post-Keynesian endogenous money view, it is recognized that money (in the form of bank deposits) comes into existence alongside loans, and that the possession of money is required to make any demand effective in the market place, then the conditions 
under which the loans are extended becomes crucial. Banks willingness or otherwise to provide loans for investment purposes and for consumer expenditure sets the parameters for the level of expenditure. The analysis of `endogenous money has often been represented by the simple notion that banks set the (loan) rate of interest, and are then willing to meet the forthcoming demand for loans from credit worthy customers. But it has always recognized that the loan policy is in the hands of the banks, and not only do they set the loan interest rate, they also determine which customers are perceived as credit worthy.

The financial crisis has been a rather obvious and strong illustration of the significance of the workings of the financial sector for the level of economic activity. It is not just a matter that the financial sector generates instabilities for the real sector. But that changes in the willingness of banks to supply loans, in whom is deemed to be creditworthy will inevitably have consequences for the effective level of demand - that is the level of demand which can be backed by purchasing power. The behaviour of banks and related credit institutions become important for the economy. Their willingness or otherwise to provide loans and the terms on which they are provided impact on the level and structure of demand. The financial sector is prone to act in ways which generate bubbles and crises :

»instability is determined by mechanisms within the system, not outside it; our economy is not unstable because it is shocked by oil, wars or monetary surprises, but because of its nature« (Minsky 1986: 172).

The mainstream macroeconomic analysis prior to the NCM was bound up with the classical dichotomy and the separation of the real side (where the level and composition of economic activity was determined by supply decisions) and the monetary side (where the price level was set dependant on the stock of money). The NCM still maintains a similar separation provided that the rate of interest is set at the level of the snatural rate of interest‘, which is the rate

"which is neutral in respect to commodity prices, and tend neither to raise nor to lower them. This is necessarily the same as the rate of interest which would be determined by supply and demand if no use were made of money and all lending were effected in the form of real capital goods. It comes to much the same thing to describe it as the current value of the natural rate of interest on capital« (Wicksell I965: IO2).

Thus at the `natural rate`, a monetary economy would be viewed as mimicking a non-monetary real economy.

In heterodox macroeconomics, any notion of the neutrality of money disappears. Indeed, it is difficult (impossible?) to even envisage what a non-monetary economy would look like in order to judge the neutrality or otherwise of money. It is simply not possible to construct a model akin to the Walrasian general equilibrium framework where money is introduced as something of an afterthought to provide the unit of account. Money comes into existence via the credit process (and is extinguished when loans are repaid), and the ways in which credit is created impacts on investment, and thereby the productive potential of the 
economy. Who receives credit and who is refused credit influences the composition of demand and of investment decisions, and hence the structure of the economy.

\section{Conclusions}

Nearly three decades ago, Minsky wrote that

"from the perspective of the standard economic theory of Keynes's day and the presently dominant neoclassical theory, both financial crises and serious fluctuations of output and employment are anomalies: the theory offers no explanation of these phenomena.« (Minsky 1982: 60).

Exactly the same remarks can be made with regard to the current orthodoxy, and specifically the centre of that orthodoxy in the form of the 'New Consensus in Macroeconomicss. The financial crises, recession and rising unemployment are witness to the futility of a macroeconomic analysis which denies those phenomena.

The financial crises and the egreat recession of 2007-09 have rather obviously brought the instability of the financial sector, the impact of that instability on the real economy, and the problems of unemployment to the fore. The essential arguments of this paper are that the mainstream macroeconomic analysis fails to comprehend those issues. The mainstream analysis is firmly based on the rational agent rational expectations approach, which is then closely associated with full employment arising from market clearing and the re-instatement of Say's Law. It is also based on denying any crucial role to money and credit and a reliance on some forms of classical dichotomy. In contrast, the heterodox macroeconomics adopts a range of analyses of human behaviour and decision making, based on perceptions of how individuals and organisation really behaver. It recognizes that full employment of labour is a rare occurrence under capitalism and that insufficiency of demand and of productive capacity are major forces generating unemployment. The heterodox approach with an emphasis on endogenous money, the loan creation process and the tendency to instability of the banking system is also well equipped to analyse financial crises and their consequences.

\section{References}

Arestis, P. (ed.) (2007a): Is There a New Consensus in Macroeconomics?, Basingstoke: Palgrave Macmillan.

Arestis, P. (2007b): What is the New Consensus in Macroeconomics?, in: Arestis, P. (ed.), Is There a New Consensus in Macroeconomics?, Basingstoke: Palgrave Macmillan, 22 - 42.

Arestis, P., Sawyer, M. (2005): Aggregate demand, conflict and capacity in the inflationary process, in: Cambridge Journal of Economics, 29(6), 959 - 974.

Arestis, P., Sawyer, M. (2008): A critical reconsideration of the foundations of monetary policy in the new consensus macroeconomics framework, in: Cambridge Journal of Economics, 32(5), 76I-779. 
Arrow, K. (1950): A difficulty in the concept of social welfare, in: Journal of Political Economy, $58(4), 328-346$.

Baddeley, M.C. (2003): Investment: Theories and Analysis, Basingstoke: Palgrave Macmillan.

Bernanke, B.S. (2004): The great moderation, Speech at meeting of Eastern Economic Association, Washington, DC, February 20, 2004, URL: http://www.federalreserve.gov/ BOARDDOCS/SPEECHES/2004/20040220/default.htm.

Blanchard, O.J. (2008): The state of macro, National Bureau of Economic Research, Working Paper I4259, URL: http://www.nber.org/papers/wi4259.

Bowles, S., Boyer, R. (I988): Labour discipline and aggregate demand: A macroeconomic model, in: American Economic Review, 88(3), 395 - 400.

Brown, G. (2007): Chancellor of the exchequer's budget statement, March 2I, 2007, URL: http://www.hm-treasury.gov.uk/bud_budgeto7_speech.htm.

Carlin, W., Soskice, D. (2009): Teaching intermediate macroeconomics using the 3-equation model, in: Fontana, G., Setterfield, M. (eds.), Macroeconomic Theory and Macroeconomic Pedagogy, Basingstoke: Palgrave, $13-35$.

Clower, R.W. (1965): The Keynesian counter-revolution: A theoretical appraisal, in: Hahn, F., Brechling, F. (eds.), The Theory of Interest Rates, London: Macmillan, I03 - I25.

Crotty, J.R. (1990): Owner-manager conflict and financial theories of investment instability: A critical assessment of Keynes, Tobin, and Minsky, in: Journal of Post Keynesian Economics, I2, 519-542.

Darling, A. (2007): Speech by the chancellor of the exchequer at the London Business School, July 25, 2007, URL: http://www.hm-treasury.gov.uk/speech_chex_250707.htm.

de Vroey, M. (1997): Accounting for involuntary unemployment in neoclassical theory: Some lessons from sixty years of uphill struggle, in: Backhouse, R., Hausman, D., Mäki, U., Salanti, A. (eds.), Economics and Methodology: Crossing Boundaries, London: Macmillan.

Dow, S. (2006): Endogenous money: Structuralist, in: Arestis, P., Sawyer, M. (eds.), Handbook of Alternative Monetary Economics, Cheltenham: Edward Elgar, 35 - 51.

Driver, C. (1994): Investment theories and radical perspectives, in: Arestis, P., Sawyer, M. (eds.), The Elgar Companion to Radical Political Economy, Cheltenham: Edward Elgar, 23I - 236.

Eichner, A. (1976): The Megacorp and Oligopoly, Cambridge: Cambridge University Press.

Fazzari, S.M. (2003): Microfoundations, in: King, J. (ed.), The Elgar Companion to Post Keynesian Economics, Cheltenham: Edward Elgar, 252 - 257.

Fazzari, S.M. (2009), Modern business behavior: the theory of the active firm, in: Goldstein, J.P., Hillards, M.G. (eds.), Heterodox Macroeconomics: Keynes, Marx and globalization, London: Routledge.

Fazzari, S.M., Variato, A.M. (1994): Asymmetric information and Keynesian theories of investment, in: Journal of Post Keynesian Economics, I6, 35I - 369.

Fazzari, S.M., Variato, A.M. (1996): Varieties of Keynesian investment theories: Further reflections, in: Journal of Post Keynesian Economics, 18, 359-368.

Fontana, G., Setterfield, M. (eds.) (2009): Macroeconomic Theory and Macroeconomic Pedagogy, London: Routledge. 
Goldstein, J.P., Hillard, M.G. (2009a): Introduction: A second-generation synthesis of heterodox macroeconomic principles, in: Goldstein, J.P., Hillard, M.G. (eds.), Heterodox Macroeconomics: Keynes, Marx and globalization, London: Routledge, 3-23.

Goldstein, J.P., Hillard, M.G. (eds.) (2009b): Heterodox Macroeconomics: Keynes, Marx and globalization, London: Routledge.

Goldstein, J.P. (2009): An introduction to a unified heterodox macroeconomic theory, in: Goldstein, J.P., Hillard, M.G. (eds.), Heterodox Macroeconomics: Keynes, Marx and globalization, London: Routledge, $36-53$.

Hahn, F. (1983): Money and Inflation, Cambridge, Mass.: MIT Press.

Harcourt, G.C., Kenyon, P. (1976): Pricing and the investment decision, in: Kyklos, 29, 449- 477.

Jorgenson, D. (1963): Capital Theory and Investment Behavior, in: American Economic Review, $53(2)$, May $1963,247-259$.

Kalecki, M. (1943): Political aspects of full employment, in: Political Quarterly, I4, 322 - 33 I.

Kalecki, M. (199I): Collected Works of Michal Kalecki vol. 2, ed. by J. Osiatynski, Oxford: Clarendon Press.

Keynes, J.M. (1936): The General Theory of Employment, Interest and Money, London: Macmillan.

King, M. (2003): Speech given at East Midlands Development Agency/Bank of England dinner, Leicester, Tuesday I4, October 2003, URL: http://www.bankofengland.co.uk/publications/speeches/2003/speech204.pdf.

Krugman, P. (2009): How did economists get it so wrong?, in: New York Times, September 2, 2009, URL: http://www.nytimes.com/2009/09/06/magazine/o6Economic-t. html?pagewanted $=8$.

Lavoie, M. (2006a): Do heterodox theories have anything in common ? A post-Keynesian point of view, in: Intervention, $3(\mathrm{I}), 87-\mathrm{II} 2$.

Lavoie, M. (2006b): Endogenous money: Accommodationist, in: Arestis, P., Sawyer, M. (eds.), Handbook of Alternative Monetary Economics, Cheltenham: Edward Elgar, I7 - 34.

Lee, F.S. (1998): Post Keynesian price theory, Cambridge: Cambridge University Press.

Lucas, R.E. (1987): Models of Business Cycle, Oxford: Basil Blackwell.

Meyer, L.H. (200I): Does money matter?, in: Federal Reserve Bank of St. Louis Review, 83(5), I - I5.

Minsky, H.P. (ed.) (1982): Can IIt Happen Again: Essays on Instability and Finance, Armonk: M.E. Sharpe.

Minsky, H.P. (1986): Stabilizing an Unstable Economy, New Haven: Yale University Press.

Moore, B.J. (1988): Horizontalists and Verticalists: The Macroeconomics of Credit Money, Cambridge: Cambridge University Press.

Mott, T. (2003): Investment, in: King, J. (ed.), The Elgar Companion to Post Keynesian Economics, Cheltenham: Edward Elgar, 205 - 210.

Pasinetti, L. (1974): Growth and Income Distribution, Cambridge: Cambridge University Press.

Robbins, L. (1932): An Essay on the Nature and Significance of Economic Science, London: Macmillan.

Romer, D. (2000): Keynesian macroeconomics without the LM curve, in: Journal of Economic Perspectives, I4(2), I49- I69. 
Sawyer, M. (1983): Business Pricing and Inflation, London: Macmillan and New York: St.Martin's Press.

Sawyer, M. (2002): The NAIRU, aggregate demand and investment, in: Metroeconomica, 53(I), $66-94$.

Sawyer, M. (2009a): The central core of heterodox macroeconomics, in: Goldstein, J.P., Hillard, M.G. (eds.), Heterodox Macroeconomics: Keynes, Marx and globalization, London: Routledge, $24-35$.

Sawyer, M. (2009b): Teaching macroeconomics when the endogeneity of money is taken seriously, in: Fontana, G., Setterfield, M. (eds.), Macroeconomic Theory and Macroeconomic Pedagogy, London: Routledge, I3I - I43.

Sawyer, M., Spencer, D. (20I0): Labour supply, employment and unemployment in macroeconomics: A critical appraisal of orthodoxy and a heterodox alternative, forthcoming.

Shapiro, C., Stiglitz, J.E. (1984): Involuntary unemployment as a worker discipline device, in: American Economic Review, 74(3), 433 - 444.

Solow, R.M. (2008): The state of macroeconomics, in: Journal of Economic Perspectives, 22(I), $243-246$.

von Mises, L. (1949): Human Action: A Treatise on Economics, New Haven: Yale University Press.

Wicksell, K. (1965): Interest and Prices, Reprints of Economic Classics, New York 1965 (originally published in 1898$)$.

Woodford, M. (2003): Interest and Prices: Foundations of a Theory of Monetary Policy, Princeton: Princeton University Press. 